\title{
STUDENTS' PERCEPTIONS TOWARDS THE IMPLEMENTATION OF MALL IN ENGLISH LEARNING: A CASE IN SENIOR HIGH SCHOOL
}

\author{
Adhitias Dewi Helda Ningrum; Farouk Imam Arrasyid \\ Syekh Nurjati State Institute of Islamic Studies (IAIN), Cirebon \\ adhitias14@gmail.com, Imam_farouk@yahoo.com
}

\begin{abstract}
In this 21st century era therm of Mobile Assisted Language Learning becomes a part of teaching and learning activity in English Education. Mobile Assisted Language learning offers various benefits to both teachers and students. Though, it offers various benefits, in practice it is still debatable thing. Thus, this research was tried to investigate students' perception towards the implementation of MALL in their learning process. The research was taken at Senior High School in SMAN 1 Dukupuntang. This current study uses descriptive qualitative method, and the data were collected through open-ended questionnaires and interview to get the relevant data. The present research shows that students tend to have good perception on the implementation of MALL in English Learning. In using MALL, students use several applications and software to help them study about English Language both inside and outside the classroom. By using MALL, students feel that it was more enjoyable and able to get the information quickly. This research also shows the challenges that faced by the students when they use MALL in English Learning activity. In conclusion, this research shows that students' have positive perception towards MALL in English Learning.
\end{abstract}

Keywords: English language learning, MALL, students’ perceptions.

\section{INTRODUCTION}

The implementation of new technologies in English language teaching of 21st century has gained considerable to the importance both in literature and in classroom practice. The issue was caused by the rapid growth of technology from time to time (Kukulska-Hulme \& Bull, 2009, p. 16). One of the current developments in 21st Century English Language Education is the use of mobile devices. It becomes a part of learning tools which helping teachers and students along the learning process inside and outside of the classroom. Mobile-based learning will make more students centered learning activities. Thus, students become more active in learning process and teachers will have a role as a facilitator that will guide students to study.

The term of mobility offers to have the opportunity to do the certain activity not dependent to one location and one time. People may do the activity in any location and any time. This term has been implemented in educational context too. Thus, the learner may study outside the classroom. The use of mobile phones, or any other potable device is starting to have big impact on how the learning takes place in any disciplines and context, including language learning. Here, this 
term called as Mobile Assisted Language Learning (MALL). MALL is different from CALL (Computer Assisted Language Learning) in its use of personal, portable device that can be carry out in any places, and its spontaneity of use. Among all kinds of technology that available nowadays, mobile phones are the most popular ones and outnumber personal computers, and they have an important place particularly in young generation (Kwangsawad, 2019).

Using mobile assisted language learning in English language teaching can create new a style of teaching rather than old fashioned direct instruction (McQuiggan, Kosturko, \& Sabourin, 2015, p. 3). For example, let us take a look in a case where students often find difficulty in learning vocabulary and how to differentiate among verb, adjective, adverb, and noun, in this case MALL can help students by providing easy accessibility to find the words that they needed. In teaching learning process faces many problems, for example, when the teacher explained some topics, some of students look bored, annoying their friends, they could not keep silent, etc. Furthermore, mobile assisted learning English activity is one of way how to solve the problem. Thus, education will less stressful, more relaxed, and more enjoyable, bringing a long list of educational.

Wanger et al. (2016) shows in his research that the perception of the respondents is positive. They believe that MALL is a good term that can be implemented in the learning process to help students and teachers doing the activities. MALL wad bing used to help students in reading ebook, playing audio, opening offline dictionary. Santosa (2017) both students and teachers faced some changes in their learning styles and the things which are needed. The growth of technology nowadays effects the way teaching and learning process that being held. One of the terms were affected by technology is the use of mobile technology in educational process. This term is well known as mobile assisted language learning and mobile learning.

A research done by Widiana (2018), said that students have different opinion on the implementation of mobile technology in learning process. This research done in 2018. It shown that students who have mobile technology tend to have good perception than those who not having good gadget. In that research, the researcher shows that the factors that had big impact was performance expectancy. Moreover, Azli, Shah, and Mohamad (2018) found that respondents had positive perception toward implementation of MALL in the Classroom. They assume that its implementation in classroom can gained students' English skills. Oz (2015) states that the successful integration of mobile technology in English learning does not depend on the technology itself, but it depends on the awareness of the teachers and the students. Therefore, it is important to know users' perception, thus to make the implementation of MALL can achieve the successfulness.

Despite the existence of research focusing on many aspects of MALL in language teaching, it was still a rare case that MALL being implemented in English Learning in Indonesia especially in the region of Cirebon. The literature still lacks sufficient research describing the perception of students' about implementation of MALL inside and outside the classroom which is now happen because of pandemic period, due to fill in the gap and expect to give a new insight the researcher tries to explore the perception of students about the implementation of mobile devices in the senior high school inside and outside the classroom. According to Lindsay and Norman in Jerry (1977. 
P. 161) defined that perception is the process of people organize and interpret the stimulation of sensory receptor in the eyes, nose, tongue or skin to produce a meaningful experience of the world. It can be understood that perception is the process started from vision to form a response that occurs within the individual. With the perception, the individual will be aware of the circumstances around him.

Technology Acceptance Model (TAM) is tailored to is contexts, and was designed to predict information technology acceptance and usage on the job. TAM has been widely applied to a diverse set of technologies and users. 1) Perceived Ease of Use: "the degree to which a person believes that using a particular system would be free of effort" (Davis 1989, p. 320). 2) Perceived Usefulness: "the degree to which a person believes that using a particular system would enhance his or her job performance" (Davis 1989, p. 320). From the result of the questionnaires of the students, there are two perception toward the use of mobile technology in the learning process. Those are the ease of use and the usefulness of mobile technology. Mobile technology become an interesting, and enjoyable supporting teaching.

In the end, the findings of this current research can be a foundation for further observation in similar and different areas and further questions can be directed to what are the strategies that can be applied in m-learning of 21 st century era. The pandemic era also changes the condition of our life. People start to be pushed into a new normal system which is creates some changes in the aspects and parts of their life. The changes in the educational system is, teachers and students should conduct the teaching and learning process through distance learning by using the mobile technology. Thus, it was one of the reasons the researcher did this research to explore the way of teaching through the distance learning. The School is SMAN 1 Dukupuntang at XII grade. The reasons of choosing SMAN 1 Dukupuntang as a place for conducting the research because that school already implemented MALL in their learning activity inside and outside the class. The senior high school students are the native user of mobile devices. They are categorized as gen $\mathrm{Z}$ which has characteristics a heavy user of mobile devices (Dolot, 2018, p. 46). They already aware how mobile devices can help them in so many aspects that they cannot be separated and avoid.

\section{METHOD}

This research used descriptive qualitative method. Fraenkel, Wallen and Hyun (2012, p. 426), qualitative research is research studies that investigate the quality of relationships, activities, situations or material. This research design focused on the teacher and student's behavior in using mobile device in the learning process. This research is formed by using descriptive qualitative method. It is defined as a research about describe group activities or event with focus structure, attitude or behavior (Ary, 2002).

The technique of collecting the data by using interview, open-ended questionnaires, and documentation. Interview is often seen as a core method in qualitative research, where the focus is on the nature of experience (Heigham \& Croker, 2012, p, 183). Open-ended questionnaires are those that require respondents to answer in their own words by writing in a space that is provided 
(Heigham \& Croker, 2012, p, 201). Creswell and John W (2012. P. 223) state that a valuable source of information of public and private records that qualitative researchers obtain about a site or participants in a research, and they can include newspapers, minutes of meetings, personal journals, letters, lesson plan, picture, etc.

The subject of this study are the teacher and the XII grade students of SMAN 1 Dukupuntang. The researcher took a teacher as an interviewee, and 50 students as the respondents of the questionnaires. The instruments that being used in this research are interview protocols, questionnaires, and documentation. The interview protocols were used to get the data about the implementation of MALL from the teacher. The questionnaires were formed as open-ended questionnaires, and it was used to get the data about students' perception towards the implementation of MALL. The last instruments, documentation was used as the supporting data.

After collecting the data from the interview and questionnaires, the researcher did the analysis by using three stages of Miles and Huberman (2014), those are data reduction, data display, and data conclusion drawing/ verification. The first, Data reduction, it refers to the process of writing summarize coding, teasing themes, making clusters, making partitions, writing memos, and selecting, the data that appear in the transcriptions that the researcher got. The second is data display, it was an organized, compressed assembly of information that permits conclusion drawing and action. The last, is conclusion drawing and verification. In this phase, drawing and verification, as result of analysis which present preliminary belief, is still tentative and would be changed if there is no evidence to prove the data collection at the next step. Then it were tested for reliability and validity through triangulation.

\section{FINDINGS \& DISCUSSION}

This session describes the findings and the discussion related to the data that being needed. The result of the data was taken from the open-ended questionnaires and interview. The data which are described the students' perception toward the implementation of MALL in English Language Learning. Also, this current research will show the obstacles that being faced by the students when they were using MALL.

Table 1.1 Kinds of MALL that being used

\begin{tabular}{|c|c|l|}
\hline No. & Types of mall & \multicolumn{1}{c|}{ The use of mall } \\
\hline 1 & Laptop & $\begin{array}{l}\text { To shows some videos to attract students' } \\
\text { interest }\end{array}$ \\
\hline 2 & Smartphones & To records video or audio as students' project \\
\hline 3 & Web browser & Searching more materials quickly \\
\hline 4 & Youtube & Watching video related to materials that needed \\
\hline 5 & Google Classroom & $\begin{array}{l}\text { To share assignment and collecting students' } \\
\text { task }\end{array}$ \\
\hline
\end{tabular}




\begin{tabular}{|c|c|l|}
\hline 6 & Quizizz & $\begin{array}{l}\text { To assess students' understanding of the } \\
\text { materials }\end{array}$ \\
\hline 7 & Discord & To explain the materials through voice call \\
\hline 8 & Whatsapp & To share information about assignment \\
\hline 9 & Online Dictionary & To find unfamiliar words easily \\
\hline 10 & ELSA Speak & To train students' speaking and listening skills \\
\hline
\end{tabular}

To begin with, based on the data obtained from the questionnaires, the students revealed that they both use kinds of MALL which are software and hardware. According to the data from the questionnaires, all of the students use laptop, smartphones, internet, web browser, applications such as ELSA SPEAK, and Quizizz, etc. in order to help them study English. From the findings it shows that students of SMAN 1 Dukupuntang use several kinds of MALL to help them in Learning English. That data was taken from the online questionnaires that was delivered to the students of XII grade. From the use of MALL in learning activity, students revealed some perceptions towards its implementation. Here are some students' perceptions towards the implementation of MALL in learning activities:

\section{a. Mobile Technology Makes Teaching and Learning Activities Fun, Interesting, and Easier}

From the questionnaire that have shared to the students, they stated that using mobile device in the learning process and activities is a good movement. They think that by using mobile technology can create a fun and interesting learning activities. The integration of mobile technology in learning activity promotes different types of learning activities than conventional learning which not using technology. By using mobile technology, the teacher can add interesting ways of doing explaining the material, for example by showing videos through the laptop, playing music, and etc.

To start with, In the students' perception of the implementation of MALL, it can be concluded that the students' perception toward the use of MALL in English learning was mobile device is ease and usefulness to use MALL in English learning. The students revealed that they think mobile technology makes the teaching and learning activities fun, interesting and easier. It was because they utilizing mobile technology to support in doing some activities. By using mobile technology, the teacher can add interesting ways of doing explaining the material, for example by showing videos through the laptop, playing music, and etc. not only for helping deliver the material, but also in assessing students' understanding. Teacher may use Quizizz, as a tool to assess students' knowledge. The quiz can be held in an interesting, and fun way. Here students' statement of MALL:

"The implementation of MALL in learning activities was good. It makes me enjoy the learning activities."

"The use of mobile phones is easy. We can use audio player to play music in the beginning of the class. We also use ELSA Speak to improve our speaking and listening skill, and that was interesting." 
Most of the students revealed that integrating mobile technology is fun, and can gaining their motivation in studying English. They already accepted it by using mobile technology to help them in learning English. It also makes the learning process easier because they have access to the internet to help them find some materials that they could not find from the book. As in a research done by Widiana, Santosa, and Myartawan (2018) that the respondents revealed, using MALL was easy and valuable. Moreover, Nobre and Moura (2017), in their research shows that Quizizz can be applied in learning activities as a game to train their vocabulary knowledge. Also, in collecting the assignment or project which given by the teacher, students can easily collect the assignment or project through Google classroom. Though, in fact from the result of interview and questionnaires there is a gap that students who doesn't have good access and good mobile device think implementing MALL was quite complicated.

\section{b. Mobile Technology can Accessing Information Quickly}

One of the results concerning about students' perception toward the use of mobile technology especially mobile phone in English learning activity is students stated that mobile technology is a useful tool. Mobile technology can help them in doing the assignment easier. They can utilize mobile technology especially mobile phone to find the materials that they need for completing the assignment and task that was given from the teacher. The other perception of students is they believe that mobile technology can help them to get the information quickly. Chartrand (2016) said that both learner and teacher able to find the materials or information that was needed through MALL, because it provides internet connection. For example, when they need to find unfamiliar words, they just need to types the words in the offline or online dictionaries, then they will get the meaning of it just in split second of time. It doesn't need take a long time, like when students use printed dictionary.

"Using online and offline dictionary, we able to find the meaning of unfamiliar words easily."

"When we need to find the information or material that could not be found in the book, we ale to find it on the internet."

One of the most useful thinks that the students claimed is it is easy to know an unfamiliar word by looking for the online dictionary, but practically in the classroom, the teacher did not allow the students to use smartphone just for finding an unfamiliar word, thus they need to look for it without the knowing of the teacher. In the research that was conducted by Porabad in 2016, he said that the students of his research think that using mobile device has possibility to the immediate feedback from the teacher, while in this current research, there is no students who think about this matter. Also, when using mobile technology for reading an e-book, it will make students easier to find the pages of the topic that they want to read. 


\section{c. More Productive Activities}

Technology is a system that can facilitate educators and students to learn more broadly, and also more variety. By doing different kinds activities, students become more productive in doing kinds of practices and exercises. They can experience lots of assignment projects with utilizing mobile devices and its applications. Students' revealed:

"Using MALL help us to solve the problems that appear when learning English, thus we can move to other activities."

"Because of the implementation of MALL, it helps us to experience different kinds of activities and that was so interesting."

Technology is a system that can facilitate educators and students to learn more broadly, more and also more variety. The different kinds of activities should increase the skills of reading, writing, listening, and speaking. From the result of teacher interview here are the transcription. Kwangsawad in 2019 did a research and found that the students agreed that EFL classes that use MALL are more productive than those without. They could access authentic materials from the website that could be use right away and then inform to the group discussion. Other language learning resources, such as online dictionary was the most frequent resource that students used. Moreover, there are plenty of podcast that can be selected as the learning material to train their listening skills. Those podcasts are available to be downloaded, some of them are free downloaded, but there are also that needed to be purchased. In conclusion, by doing different kinds activities, students become more productive in doing kinds of practices and exercises. They can experience lots of assignment projects with utilizing mobile devices and its applications. For example, students being told to make short conversation video about invitation.

\section{d. Improving Students' Skills}

Most of the students think that mobile technology can improve their four skills (reading, writing, listening, and speaking). In line with Chartrand (2016) that argue, students can reach the target of English language learning by using MALL in the learning activities. Thus, students perceive that mobile technology allows them to practice their English more. They stated that kind activities which are can improve their skills is mostly by utilizing mobile phone. Most of the students think that mobile technology can improve their four skills (reading, writing, listening, and speaking). Those students perceive that mobile technology allows them to practice their English more.

Students stated that kind activities which are can improve their skills is mostly by utilizing mobile phone. The students told that before the pandemic period, for increasing students' speaking and listening, she instructs the students to use ELSA Speak and watching video from teacher's recommendation as the media of self-learning. While for teaching reading 
and writing, teacher use some kinds of exercises for example by asking them to find the references of the materials that being discussed and write down the summary. They may also use Grammarly for checking their writing.

Although, the students said that their skill was improved, the evidence of the interview and screenshot shows that they still having difficulties in doing conversation by using simple English language. Moreover, they seem have good perception of the usefulness of mobile technology, they also think that mobile technology sometimes has difficulties. From the result of the interview in the findings, the students often do complain about low connectivity and the signal that was not stable. The other problems shown in the findings is unsupported phone. From the interview of the students, there is a few of them that have old fashion mobile phone, so they often get trouble in using it. Those are similar to the issues that shown in the journal written by Kangsawad (2019). Other technological problems and difficulties in mobile learning include technical problems of operating the device. That was the opposite perception of the students' perception on Hui Chung (2015) research, he revealed that learning using mobile phone is not restricted by the time.

\section{a. Using MALL was quite troublesome}

Although the use of MALL seems like creates many advantages, there are students who revealed bad perception towards the implementation of MALL. Using MALL helps students in learning activities, they also find it has its own demerits for both teacher and students. The problems are low connectivity, high cost, technical challenges, limit time, risk of distraction, and risk of cheating.

\section{b. Low connectivity}

The First problem when students use mobile technology was low signal. The term of 'anytime, anywhere' capabilities of mobile devices encourages learning experiences outside of a teacher-managed classroom environment. Some of the students said that they have a problem about internet connectivity. It was difficult to connect their mobile phone to the internet because of the low signal. Several factors can affect the speed of access data, including distance between the server and the user, internet traffic conditions, signal strength and technology used by internet service providers.

When students have a low signal, students could not connect to the internet or open some applications. Students only wait until the signal was normal and could to connect to the internet. According to students who had been interviewed, they said that the problem they often faced when they want to send the assignment was low signal. Signal was the important part when used a social media. They explained that, signal had a big effect for sent assignment and joining the online class. When they had a high connection, they would fast to send assignment and join the class on time, but when they had a low connection, they would get a problem to send the assignment, and if they get late joining the class it will affect their attendance. 


\section{c. Unsupported phone}

Different kinds of mobile device that being used may influence the performance on the learning process. The students who have old mobile phone sometimes could not be used supposedly. Some of them often get problems when opening some applications, and downloading some files. Their mobile phones will get lagging in opening applications, and they could not download the file because of the available of the memory is not enough.

"I have an old model of phone, so it often slows response, and sometimes it doesn't support applications or features that are used recently."

"My phone often restarting and crashing randomly."

"The storage of my memory phone is full, thus it often gets slow in opening the applications that being used for study."

\section{d. High cost}

Using too much connection with the internet will cause another problem which is high consuming on the internet package. One of the big impacts of pandemic period is the activity of teaching and learning process could not be held in the class room in face to face. The teaching and learning process need to be held through distance learning or mobile learning in which students doing the learning process though online meeting. Spending too much time on the online meeting will cause spending much internet package. The cost of a good internet provider is quite expensive. If the students who does not use Wifi in their house, it will cost higher payment for the internet connection than the others who have Wifi. There are so many students that said about the high cost of the internet package. One of the students stated:

"The problems is when I do not have internet package. The price of the internet package is quite pricy and the signal is to slow."

\section{e. Risk of distraction}

Aside from physical considerations, educators need to ensure that mobile devices in the classroom are not used for activities other than learning. It's easy for the students to chat with friends, play games, watch funny videos, access social media sites, and even answer calls. After all, smartphones and tablets are communication devices, thus the teacher need to maintain their activity in the class, so students could not play their mobile phone other than using it for doing the learning activity. Here are some students' statement about the risk of distractions. Here are the statements of the students that said the distraction of using mobile device often happen in the classroom. 
"Students not focus in learning process. Smartphone can distract students during the teaching and learning process. They could be distracted by checking text messages, games and others, students will open a social media account or chat online compilation has been opened."

Students can open some social media, watch videos, and listen to music on their mobile phone. Multitasking may save them a lot of time, but it only acts as a deterrent when it comes to effective learning. It can prevent the mind from concentrating on the subject and keeping knowledge. The importance of the course can be diluted by ongoing social and entertainment activities on mobile devices. This need to be considered that teachers really need to make strict policy in the classroom about the use of mobile phone. Not only making the strict policy, teachers also need to guide the students to guide the students in gaining their responsibility of using technology wisely. This action will be decreasing the risk of distraction if the students willing to follow the teachers' effort.

\section{f. Risk of cheating}

Cheating is a risk thing that could be happen when using mobile device especially mobile phone in the learning process. Those students which take this situation to do bad things will use mobile device for searching the answer of their task without being permitted.

"The easiness of using mobile technology makes some students do plagiarism, and cheating in doing their assignment."

The strength of today's cell phones allows students a variety of opportunities to cheat on examinations. Thus, during the examination period, there are students that communicate with fellow students on a continuous basis. Using a cell phone camera, a student can take a snapshot of questions and send a Whatsapp massage to the other students to help them answering the question, in the same way possible that a student can provide answers. In fact, because a cell phone has internet access, students can post questions online and provide answers instantly. The students who cheat in the classroom usually take advantage of the situation when the teacher not looking at them, they do cheat to search the answer of the assignment even though the teacher didn't allow them to use their mobile device. Some of them also share the answer through one another through Whatsapp. Although technology makes the teaching become easier and interesting, if the implementation is not good enough it can cause troubled and disadvantages.

\section{CONCLUSION}

This present research was aimed to find out the students' perceptions towards the use of MALL in English Language Learning. The perceptions were taken from the sight of ease of use and usefulness. Regarding to the findings and discussion that have been elaborated above, the researcher revealed that although it was found that there are some problems and challenges faced 
by the students in using MALL, they still think that MALL is a useful tool to be used. Therefore, it can be concluded from the result of the research that the use of MALL in English Language Learning is an important thing that needed to be considered, because technology play a significant role in education, it is necessary for language teachers to integrating the language teaching. Thus, implementation of new technologies in English language teaching of 21st century has gained considerable to the importance in classroom practice. It is necessary to the way teacher use mobile technology and the applications to support the learning process.

\section{REFERENCES}

Ary, D. (2002). Introduction in research in education. Belmonth: Wardsworth Thomson learning.

Creswell, J. W. (2012). Educational research; planning, conducting, and evaluating quantitative and qualitative research. Boston: Pearson Education.

Dolot, A. (2018). The characteristic of generation z. E-mentor, 2(74), 44-50, http://dx.doi.org/10.15219/em74.1351.

Hancock B., Windridge K., \& Ockleford, E. (2009). An introduction to qualitative research. The NIHR RDS EM / YH.

Heigham, J., \& Croker, R. A. (2012). Qualitative research in applied linguistics: a practical introduction. Basingstoke: Palgrave Macmillan.

Kangsawad, T. (2019). University students' perceptions of mall in efl classes. Studies in English Language Teaching. doi:10.22158/selt.v7n1p75

Kennedy, C., \& Levy, M. (2008). L'italiano al telefonino: Using sms to support beginners ${ }^{\text {ee }}$ language learning. ReCALL, 20(3), 315-330.

Kim, Hea-Suk. (2013). Emerging mobile apps to improve english listening skills. MultimediaAssisted Language Learning, 16(2), 11-30.

Kukulska-H, Agnes (2018). Mobile-assisted language learning [Revised and updated version]. In: Chapelle, Carol A. ed. The Concise Encyclopedia of Applied Linguistics. Wiley.

Kukulska-H, A., \& Bull, S. (2009). Theory-based support for mobile language learning: Noticing and recording. International Journal of Interactive Mobile Technologies, 3(2), 12-18.

Kukulska-H, A., \& Traxler, J. (Ed.). (2005). Mobile learning: A handbook for educators and trainers. Oxon: Routledge.

Kwangsawad. (2019). University students' perception of mall in efl classes. Studies in english language teaching. SCHOLINK INC. http://dx.doi.org/10.22158/selt.v7n1p75

Lindsay, P. H., \& Norman, D. A. (1977). Human information processing: An introduction to psychology. New York: Academic Press.

McQuiggan, S., et al. (2015). Mobile learning: a handbook for developers, educators, and learners. USA: SAS Institute Inc. 
Miangah, T. M., \& Nezarat, A. (2012). Mobile-assisted language learning. international journal of distributed and parallel systems, 3, 309-319. doi: 10.5121/ijdps.2012.3126.

Miles, M. B., Huberman, A. M., \& Saldaäna, J. (2014). Qualitative data analysis: A methods sourcebook (Third edition.). Thousand Oaks, Califorinia: SAGE Publications, Inc.

Pachler, N., Bachmair, B., \& Cook, J. (2010). Mobile learning: Structures, agency, practices. London: Springer.

Sato, T., Murase, F., \& Burden, T. (2015). Is mobile-assisted language learning really useful? An examination of recall automatization and learner autonomy. In F. Helm, L. Bradley, M.

Sharples, M., Sanchez, I. A., Milrad, M., Vavoula, G. (2007). Mobile learning: small devices, big issues.

Reading, UK. Retrieved from http://cloudworks.ac.uk/cloud/view/3472

Valarmathi, K. E. (2011). Mobile assisted language learning. Journal of Technology for ELT, 1(2).

Widiana, P. A, \& Santosa. (2018). Tenth grade students' perception toward mobile assisted language learning (mall) in learning english in buleleng regency in academic year 2017/2018. e-Journal JPBI Universitas Pendidikan Ganesha Jurusan Pendidikan Bahasa Inggris. 